\title{
ENTREVISTA COM FRANÇOIS RASTIER \\ DIALOGUE AVEC FRANÇOIS RASTIER
}

\author{
Alexandre Gilbert \\ galeriechappe@gmail.com \\ 19 JULHO 2018
}

François Rastier, linguista, semanticista e diretor de pesquisa no CNRS, é autor de Naufrage d'un prophète. Heidegger aujourd'hui, publicado em 2015 em Presses Universitaires de France e Heidegger, Messie antisémite , lançado em 2018 em Le Bord de l'eau, collection Clair et net.

\section{AG - 0 senhor publicou em 2005, Ulysses em Auschwitz. Primo Levi, o sobrevivente. Como você explica o luto impossível do fascismo e a sobrevivência do anti-semitismo e das teorias heideggerianas na Itália.}

FR. - Sua pergunta, infelizmente, vai muito além da Itália. No final do livro que você mencionou, encontrei-me na situação de um judeu, embora não o seja. Primeiro me perguntaram se eu era judeu, discretamente surpreso com a minha resposta negativa. Mas por que eu deveria sê-lo? Cada grupo e cada religião devem preocupar-se apenas consigo mesmos? 0 extermínio afeta cada um de nós e é por isso que Levi não apresentou seu judaísmo. 0 status do sobrevivente não foge a essa forma paradoxal de universalidade: todo mundo que lê Levi descobre que a experiência dele pode e poderá algum dia se tornar a sua própria. Logo, recebi algumas ameaças antissemíticas, públicas e privadas, cujo absurdo ameaçador mostra as notícias crescentes de Levi, principalmente quando as categorias e a linguagem que permitiram o extermínio se tornaram cada vez mais proeminentes no espaço cultural. ou pelo menos ideológico.

A ameaça está presente. Adquirida no quadro profissional de um projeto europeu de detectação multilíngue de sites racistas, a frequência de clássicos do nazismo e a atual literatura negacionista me confirmaram a ideia de que o radicalismo político de autores como Schmitt ou Heidegger permanecia pesado de ameaças, o que lhes valia, sem dúvida, muitos elogios hoje, de Agamben a Negri, de Badiou a Zizek, e de serem a referência indiscutível para muitas das correntes de identidade cultural e pós-colonial.

As teorias obscurantistas da conspiração são difusas. Os chamados partidos populistas (eufemisticamente) que participam de vários governos têm radicalizado observações claramente xenófobas. As mortes e assassinatos racistas estão se multiplicando. Queríamos fazer de Auschwitz uma derrota do humanismo, do racionalismo, uma continuação lógica do Iluminismo. Por trás dessa ascensão do anti-humanismo, afligido no pós-humanismo, o racionalismo de Levi, seu compromisso com o Iluminismo (a razão não está morta em Auschwitz), a humildade científica, a tolerância, a democracia, e até mesmo a proteção da natureza não têm nada de curiosidade terna e levemente desatualizada. Em suma, a ameaça ambiental é hoje redobrada por uma ameaça política e ideológica. Você menciona a Itália e ela não é exceção: desde as últimas eleições, ela faz parte do Eixo que o chanceler austríaco evocava, recentemente, em Berlim, diante do Bundestag. 0 antissemitismo ameaça o próprio conceito de humanidade, mas também a cada um de nós. "Antes de cada massacre", relembra Rithy Panh, "há uma ideia". 0 alvo do ódio assassino permanece, simplesmente, uma pura variável. Todo mundo se lembra de que os skins de Reims, indo à caça do árabe matam um homossexual. Ele está, constantemente, se ampliando e o extermínio também afetou os ciganos, depois os mestiços e os deficientes mentais. 
Assim, o antissemitismo não termina com os judeus. Em seu nacionalismo fanático, o ódio identitário foi teorizado por Heidegger (O Ser e o Tempo, 1927), quando ele transformou a questão antropológica "0 que somos nós?", aliás, presente no judaísmo (0 que é, então, o mortal?) e, em questão identitária, a «Werfrage»,"Quem somos nós?". Derrida retomou e radicalizou com a pergunta "quanto somos nós?" Como isso, obviamente, não se trata de um censo da população, esse "nós" supõe algo comum, a fundação da comunidade, como também exclui, de fato, aqueles que escapam da enumeração. Nancy escreve em sua Banalidade de Heidegger: "Não gostamos nem de judeus, nem de técnica, nem de dinheiro, nem de comércio, nem de racionalidade - pelo menos nunca deixamos de colocá-los à distância" omitindo, no entanto, malgrado esta figura de participação, especificar quem designa esse "nós". A divisão e a dispersão de identidades tiveram um efeito devastador sobre as forças do progresso: a identidade sempre reforça a extrema direita. Concepções identitárias, sejam elas nacionalistas, populistas ou pós-coloniais, são consistentes com a tradição de pensamento, do qual Heidegger deu uma síntese eficaz. Os oprimidos se engajam em se dividir em comunidades: nacionais, étnicas, linguísticas, sexuais ou de gênero, que rivalizam entre si, mas incluem, de bom grado, os opressores que dominam sua retórica identitária. Segue-se um recuo geral das forças democráticas, descritas como agentes do imperialismo, embora a democracia tenha conhecido experiências espontâneas em todos os continentes (ver Amartya Sen, The Democracy of Others, Paris, Payot / Rivages, 2005). A própria noção de antifascismo parece ter-se tornado uma era vintage ${ }^{1}$.

\section{AG - Em 2015, o senhor publicou Naufrágio de um profeta. Heidegger hoje. 0 que você aprendeu no último opúsculo dos Cadernos Negros que permite ter uma visão mais profunda do pensamento do filósofo alemão?}

FR. - A filosofia heideggeriana é considerada como fundadora, em particular na França, notadamente onde várias gerações de discípulos se sucederam, do existencialismo sartriano, que cede lugar, após um episódio marxista, ao desconstrucionismo embora tenha dado matéria ao idioma dominante que fez o fundo da disciplina acadêmica e da Teoria francesa. Ora, a situação mudou, significativamente, desde 2014, apresentando um contraponto radicalizado ao trabalho já publicado, os primeiros quatro volumes dos Cadernos Negros. Eles renovaram, completamente, a leitura de Heidegger e sua recepção de que o próprio estatuto de sua filosofia estava colocado em questão, embora a publicação de sua obra ainda esteja em andamento e obedeça a uma estratégia dilatadora que ele planejou, cuidadosamente, e que faz dele um autor deste século.

Durante muito tempo, certa opacidade permaneceu. Depois da guerra, Heidegger reescreveu seus textos menos ambíguos e se envolveu num certo hermetismo adocicado. Sem dúvida, a seu pedido, seus detentores de direitos e editores proibiram, até agora, o acesso a seus arquivos. Mas ele planejou, cuidadosamente, a publicação de suas obras completas, conduzindo-as a uma radicalização progressiva que atingiu o limiar no início deste século. Foi, assim, em 2001 com um texto que pede o "extermínio total" do inimigo interno; depois, os nove volumes que reagrupam os Cadernos Negros vão coroar o fato por inteiro. As seções publicadas até hoje retomam, nos mesmos termos, as teses de Hitler e Rosenberg sobre o "domínio judaico mundial".

Vindas depois das profecias de Hitler sobre a eclosão da guerra pelos judeus, repetidas de 1939 a 1942, essas propostas radicalizam ainda mais o antissemitismo. Era necessário conceber e justificar o projeto de aniquilamento total. Essa era a especificidade dos ideólogos nazistas, entre os quais Heidegger que ocupa o lugar mais importante no cenário

\footnotetext{
${ }^{1}$ Estilo de vida e moda retrógrada, uma recuperação de estilos das décadas de 1920,1930, 1940, 1950 e 1960 [NdT].
} 
internacional. Seu antissemitismo, obviamente, não se limita a reformular os clichês sobre os judeus dos lugares comuns, o que seria complacente, mas deve ser esclarecido por sua estratégia em relação ao extermínio.

a) Oito anos antes da conferência de Wannsee, ele formulou, publicamente, o projeto em 1934, incitando seus alunos a "prepararem-se para o ataque" e a "aniquilação total" ["völligen Vernichtung"] do "inimigo incrustado na raiz mais íntima do povo" (GA 36-37, p.90-91). No entanto, ele não nomeará, publicamente, esse inimigo parasitário de maneira tão precisa quanto em Cadernos Negros, quando de sua publicação oitenta anos depois.

b) Ele afirma que "o ato mais alto da política" é "envolver o inimigo em uma situação em que ele é forçado a realizar seu autoextermínio" [Selbstvernichtung] (GA 96, p.260). Este novo "argumento" revelado pelos Cadernos Negros permite-lhe sustentar que os judeus foram aniquilados por eles próprios. Heidegger, especificamente, tematizou essa autodestruição: "É quando o essencialmente "judeu", no sentido metafísico, luta contra o judeu, que a auto aniquilação atinge seu auge na história".

c) Depois da guerra, ele prepara a negação ontológica das vítimas do extermínio e o apagamento de seus assassinos - assim, em um único e pequeno parágrafo, ele incrimina, em seu lugar, a industrialização (da agricultura ...), como também a Bomba $\mathrm{H}$ americana e o bloqueio de Berlim pelos russos.

d) Finalmente, como não é suficiente matar homens, é preciso, também, erradicar as ideias e, assim, aniquilar o judaísmo: isso somente pode ser feito de dentro, mobilizando discípulos judeus, seduzindo o público judeu, cuidando de iscas messiânicas.

Paralelamente à evolução da pesquisa, a figura decidida do Pensador, retirado para sua cabana na Floresta Negra, depois de um curto período de loucura improdutiva, tornou-se um estereótipo apologético agora, desatualizado. A publicação dos primeiros Cadernos Negros e de correspondências e seminários, até agora inéditos, permitem estabelecer que esse pensamento filosófico foi elaborado pela criptografia de uma mística de sangue e solo, por um sistema de alusões, silepses etimológicas, palavras de cobertura que o Mestre chama de Decknamen. Essas novas publicações, que se multiplicaram desde 2015, abrem a questão do ativismo heideggeriano, cuja extensão e consequências reais começam agora a ser mensuradas.

\section{A.G. - 0 senhor evoca a jornada de Ahmed Fardid que introduziu a filosofia de Martin Heidegger no Irã. É também o tema da última obra de Bernard Henri Levy, O Império e os Cinco Reis. Pode nos explicar que influência Heidegger teve na Revolução Islâmica?}

FR. - Não vou comentar o livro de Bernard-Henri Lévy, que continua sendo um apoio inabalável a Heidegger, como ficou evidenciado na sua contribuição aos trabalhos da conferência Heidegger e aos "judeus" que ele publicou em 2016.

Se o antissemitismo identitário de Heidegger é apreciado, favoravelmente, por alguns islamitas sunitas, é no xiismo político que Heidegger tem obtido maior eco. Certamente, em Deconstructing Zionism, Vattimo aprova Ahmadinejad, mas ele permanece em silêncio sobre o heideggerismo não oficial no Irã. Ora Henry Corbin, especialista nas correntes esotéricas do Islã, especialmente xiitas, foi, antes de Beaufret, o primeiro tradutor de Heidegger na França, desde 1938, antes de ir para a escola em Teerã. Discípulo e tradutor de Corbin, o filósofo iraniano Ahmad Fardid forjou a noção de "intoxicação pelo Ocidente" ("Gharbzadegi" em persa, literalmente "Westoxication"). Essa noção foi adotada por Ali Shariati, o principal ideólogo do regime. Para Fardid, é necessário denunciar a maquinação judaico-maçônica, 
inspirada pelo "obscurantismo do mundo", segundo Heidegger, para rejeitar como direitos humanos alogênicos, a democracia, a tolerância e advogar o retorno ao "autêntico eu oriental". Esse retorno justifica um antissemitismo, baseado em uma teoria tradicional da conspiração que foi ensinada por autores como Zabih Behruz e Hosayn Malek. Assim, Heidegger tornou-se uma referência para alguns islamitas hoje no poder.

A partir de Heidegger, Fardid e seus alunos elaboraram uma tripla justificativa política da teocracia iraniana:

a) adaptando o antissemitismo que não era tradicional no Irã;

b) assimilando o Seyn heideggeriano ao Mahdi;

c) Transpondo, finalmente, a teoria do Führung para o Velayat-e-faqih, literalmente o governo pelo Docte, que estabelece o aiatolá Khomeini como Guia da Revolução (Valiye faqih), chefe supremo do exército e dos Guardiões da Revolução, comandada por Ahmadinejad, treinado na Escola Fardid. Assim que Khomeini assumiu o poder, Fardid e Ahmadinejad estavam ativos no Escritório para o Fortalecimento da Unidade entre Universidades e Seminários Teológicos (Daftar-e Tahkim-e Vahdat-e Hozeh va Daneshgah), encarregados de liquidar marxistas e democratas, especialmente em 1980, o que foi, oficialmente, chamada de Revolução Cultural Islâmica.

\section{A.G. - 0 senhor mencionou também algumas referências supremacistas brancas em Susan Sontag que, como sua companheira Annie Leibovitz, era fascinado pelo cineasta Leni Riefenstahl. Como explicar o ressurgimento da popularidade da estética nazista durante a década de 60?}

FR. - Percebi, simplesmente, que, na década de 1960, Susan Sontag havia invertido um slogan antissemita dos extremistas. Os extremistas brancos já afirmavam uma ligação entre os judeus e a escravidão: para Ben Klassen, fundador do Partido Nacionalista Branco, a raça negra era "um câncer em nosso meio", importado pela escravidão judaica para desgraçar os brancos. Esta tese será revertida, mas retomada pelos extremistas negros: os judeus são responsáveis pela escravidão. Sem fundamento histórico sério, a tese faz prosperar a réplica de Dieudonné sobre "o comércio dos escravos, uma especialidade judaica no começo", até o assassinato de Ilan Halimi por Youssouf Fofana. Resta apenas incriminar os brancos em geral, e o "câncer" muda de lado, como atesta a declaração de Susan Sontag, figura histórica dos Estudos Culturais: "A raça branca é o câncer da História humana (Partisan Review, Inverno de $1967,57)$. Ela estava seguindo os extremistas negros da Nação do Islã e os Panteras Negras, de quem ela estava muito perto. Sua concepção de "brancura" está agora difundida na corrente pós-colonial, como evidenciado na obra de Houria Bouteldja, porta-voz dos Povos Indígenas da República, Os Brancos, os Judeus e Nós (2016).

Em 24/11/2001, Sontag publicou no New Yorker um artigo que elogia a coragem dos terroristas de 11 de setembro, ainda on-line em sites islâmicos. Leni Riefenstahl, em seus filmes de montanha da década de 1920, desenvolveu um pathos de força corpórea que fascinou Hitler; ele o deu como exemplo a seu fotógrafo pessoal. Este pathos desenvolve depois os deuses do estádio até seus álbuns no Nubas. Erotizado, faz o fundo comum da fotografia artística contemporânea, de Mappelthorpe a Helmut Newton. Ele se torna popular com o narcisismo em massa.

Agora o Corpo absoluto substituiu o Espírito absoluto de outrora. Seu tema antiintelectualista está de acordo com as filosofias da vida, das quais Heidegger é um representante, como outros nazistas, incluindo Ludwig Klages (a quem Derrida emprestou sua crítica ao logocentrismo e, com ele, à racionalidade). 


\section{A.G. - 0 que pensar dos escritores heideggerianos italianos mais midiáticos, como Giorgio Agamben, Gianni Vattimo ou Diego Fusaro, conselheiro do governo M5S / Lega (Verde / Amare).}

FR. - (A) Na escala internacional, o heideggerismo contemporâneo está florescendo na França, mas também na Itália e a teoria italiana, da qual Gianni Vattimo é a maior figura, deve tanto ao Mestre quanto à Teoria Francesa. Personalidade internacional da Desconstrução, Gianni Vattimo, diretor da famosa obra coletiva $O$ Pensamento débil apresentase como um "cristão heterodoxo e nostálgico". Antigo eleito do Partido Radical, ele continua sendo uma figura do radicalismo acadêmico. Seu último livro, Hermeneutic Communism, tem como subtítulo: From Heidegger to Marx. Durante muito tempo, deputado europeu pelo partido populista Itália de valores, ele afirma ser de Mao.

Vattimo aprova Heidegger por seu "corajoso" compromisso nazista: "Heidegger, aderindo ao nazismo, fez uma ação corajosa. [...] Ele envaideceu-se e implementou sua concepção pessoal de intelectual comprometido. Que, em seguida, isto seja uma ideia equivocada, é outra história. Mas ele sujou as mãos. Vattimo também retoma essa sentença do Mestre, Wer denkt gross, muss gross irren: "Quem pensa grandemente deve ser enganado com grandeza" - Heidegger fazia assim o elogio de sua própria grandeza e se colocou além do Bem e do Mal. Melhor, Heidegger teria tido a coragem de manter suas posições após a guerra, - o que o coloca como um rebelde romântico, quando "se poderia esperar dele uma" conversão "pública aos valores" humanos "do Ocidente vitorioso" (La Stampa, 2 de junho de 2012, "Ma Heidegger non era razzista").

Passemos à conversão pública, que ninguém exigiu e que, no entanto, evoca a Inquisição. Mas o argumento é surpreendente: os alemães não seriam ocidentais? (alguns os fizeram nórdicos); Os russos não são, também, vencedores? De fato, a questão do argumento é voltada, não para a Alemanha de Hitler, mas aos Estados Unidos. Por um gesto característico da lógica desconstrutiva, Vattimo refere-se, de fato, ao hitlerismo e ao atlantismo, colocandoos no mesmo plano: "É mais razoável concluir que Heidegger nunca pensou que se poderia colocar na perspectiva da verdade absoluta: nem quando ele escolheu Hitler, nem depois, quando deveria ter se tornado um filósofo disciplinado, "democrático" e atlantista", .

Vattimo declarou certa vez: "Nunca acreditei nas mentiras dos Protocolos dos Sábios de Sião. Agora estou começando a acreditar neles, de novo, dado o servilismo da mídia."Finalmente, em Deconstructing Zionism, ele vira a tradição judaica contra os judeus, é então um antissemitismo "cultural" que é elaborado. Por exemplo, diz Vattimo, "A preciosa riqueza e profundidade da tradição judaica é tão pútrida, com um ar sufocante que deve ser liberado para evitar derramar sangue pelo túmulo de Raquel". [...] "Ele, assim, devolve à tradição judaica um atributo imemorial da propaganda antissemítica, o fedor que revela a conivência dos judeus com o mundo infernal.

(B) Agamben, que acompanhou os últimos seminários de Heidegger, dedicou-lhes seu primeiro livro e permanece fiel ao autor (ver The Use of the Bodies, 2017), mesmo que ele priorize a teologia política de Schmitt.

Afirmando que, desde Auschwitz, o campo é o "novo nomos ${ }^{2}$ políticos do planeta" (0 que resta de Auschwitz, 1995, p. 56), Agamben (p. 53) dá, como exemplo, o Velódromo de Inverno e, ainda, o Estado de Bari (onde foram reunidos, em 1991, refugiados albaneses), as

\footnotetext{
2 (Filosofia - Jurídico [Termo]) A lei, segundo a filosofia grega da Antiguidade, explicada como uma convenção dependente do artifício humano ou, para outras correntes, das leis da natureza, em ruptura com as legitimações jurídicas fundamentadas na religiosidade e na tradição. Fonte:

https://www.google.com.br/search?q=nomos+significado\&oq=nomos\&aqs=chrome.2.69i57j015.6661j0j8\&sour ceid=chrome\&ie $=$ UTF- 8
} 
"zonas de espera nos aeroportos internacionais franceses" onde eram retidos os requerentes de asilo (por exemplo, o "Arcade Hotel em Roissy") e finalmente, as Gated communities nos Estados Unidos. Assim, o conceito de acampamento de boas-vindas permite colocar, decisivamente, no mesmo plano, Auschwitz e os resorts para milionários. Em linha idêntica, no Colégio Internacional de Filosofia, no final de 1997, Agamben estabeleceu, explicitamente, uma ligação entre o mulçumano de Auschwitz e Sabbatai Zevi, o falso messias herege que se converte ao Islã. Não faltou, também, identificar os "muçulmanos" de Auschwitz com os prisioneiros islâmicos de Guantánamo ou os detentos palestinos em Israel, os americanos e depois os israelenses, obviamente tomam o lugar dos nazistas.

Nesta confusão estratégica, ele pode concluir sua negação nietzschiana dos valores: os "chamados valores e direitos humanos" seriam, apenas, uma ideologia ultrapassada "Para quem não é de uma má-fé absoluta, está claro que ele não tem absolutamente nada com os homens de deveres históricos, assumíveis ou simplesmente atribuíveis" (O APERTO, 2002, p. 79). Ele rejeita as "declarações vãs sobre a sacralidade da vida e os direitos do homem" (1995: 109); e no capítulo Além dos direitos humanos (i, 2) a ruptura entre direitos e lei: "É hora de parar de ler as declarações de direitos, de 1789 até os dias de hoje, como proclamações metajurídicas eternas, cujo objetivo seria obrigar o legislador a respeitá-las" (p.31). Referências recorrentes a Carl Schmitt, o teórico nazista do estado de exceção, lançam luz sobre essas observações (ver pp.53, 97, 118). Vou levantar uma objeção, quando os direitos imprescritíveis forem abolidos, somente permanecerão "os direitos prescritíveis da pessoa humana", que Paul Rassinier, fundador do negacionismo contemporâneo, enumerava como: "o guarda da prisão, o crematório, a fábrica, a cozinha [...]" (Mentira de Ulysses, 1949, capítulo 2).

Finalmente, Diego Fusaro, nascido em 1983, pertence à nova geração, que salta da esquerda heideggeriana, supostamente radical, em direção ao neofascismo. Ele acabou de passar do jornal Il fatto quotidiano ao órgão da organização Casa Pound (Ezra Pound foi um líder da propaganda mussuliniana) Il Primato Nacionale (Preferência Nacional), onde detém a rubrica da direita populista. Definindo-se como "fascistas do terceiro milênio", os ativistas da CasaPound foram, recentemente, reconhecidos pela violência física contra os jornalistas e sua convivência mais que harmoniosa com a máfia romana em seu reduto eleitoral.

A mudança de governo tem contribuído para esta aparente metanoia de Fusaro, mas seria demasiadamente simples e descortês ver onde o oportunismo de um vira-casaca que teria, subitamente, vestido, à exemplo de Salvini, um bombeiro da moda, editado pela CasaPound. 0 slogan de Fusaro, "além da esquerda e da direita" (al di là di destra e sinistra) leva, simplesmente, à eliminação da esquerda. Então, na entrevista que acaba de ser publicada, Fusaro apresenta Gramsci, secretário-geral do PCI que Mussolini aprisiona por décadas até sua morte, como um discípulo de Gentile, que foi o ideólogo oficial do fascismo até o fim da República de Salò. Essa reescrita da história intelectual é uma ofensa final à memória de Gramsci, uma espécie de liquidação simbólica

0 acerto de contas pode até afetar os heideggerianos "de esquerda". Em uma entrevista á revista Hohe Luft, intitulada "Selbstvernichtung der Juden " (Autoextermínio dos judeus), Di Cesare, ex-vice-presidente da Heidegger Gesellschaft, disse certa vez: "Precisamos de Heidegger para compreender o Holocausto". Sua posição é ainda mais angustiante porque vive sob proteção policial, desde que sua militância sionista recebeu ameaças dos neofascistas italianos, que agora estão crescendo. Entre eles, o grupo CasaPound também reivindica Heidegger pela voz de seus principais ideólogos, como Adriano Scianca - que Fusaro há anos faz suscitar na mídia. É compreensível que Fusaro evite sua pergunta sobre ela, alegando respeito pela "vida privada" de Di Cesare. Matteo Salvini também está prestes a resolver essas 
contradições entre os heideggerianos à sua maneira, removendo a proteção policial de pessoas ameaçadas pela extrema direita.

\section{A.G. - Qual é a diferença entre George Steiner, Hannah Arendt e Leo Strauss, todos os três judeus, que se inspiraram no trabalho de Martin Heidegger?}

FR. - (I) Sobre o extermínio, George Steiner publicou, em 1971, um livro com o título um tanto quanto bizarro, No castelo do Bluebeard, que continua a ser uma referência nos círculos culturais, onde o autor goza de grande reputação, coroado com os mais prestigiados prémios. Aqui estão alguns trechos: "Há evidências de que os seres humanos são inadequados para viverem na densidade sufocante da colmeia industrial urbana. Depois de um século, o aumento do ruído, a aceleração do movimento e das cadências de trabalho, o aumento do poder da iluminação artificial, podem ter atingido um limiar patológico e desencadeado instintos de devastação" [p.63.]. A conclusão não se faz esperar: "Assim, os reflexos do genocídio do século XX, a dimensão implacável do massacre vêm, talvez, de um enxame de alma asfixiada. Este tenta encontrar o ar livre enquanto quebra as paredes da multidão que $o$ oprime" (p.64). Não se trata aqui de raça, mas da oposição entre a alma (de elite, obviamente) e os insetos (a multidão se torna colônia de invasores). 0 extermínio tornou-se, assim, um reflexo natural: "0 holocausto é um reflexo, mais intenso por terem sido reprimidas, durante um longo tempo, a sensibilidade natural, as tendências animistas e politeístas do instinto".

A grande exoneração, a de Hitler e a da Alemanha nazista, pode então ser empreendida: "O holocausto não é a consequência de um estado mórbido individual ou as neuroses de uma única nação" (p.46), mas é, consequência da cultura ocidental, tomada em geral, após a "morte de Deus": "Ao matar os judeus, a cultura ocidental eliminaria aqueles que haviam inventado Deus" (p.52). Steiner conclui: "0 antissemitismo nazista é a coroa lógica da visão cristã eterna" (1969: 186). Além disso, o monoteísmo judaico torna-se ele próprio a causa do extermínio: "Ao longo da história, o monoteísmo absoluto revelou-se quase intolerável" (p.50). Os assassinos, portanto, agiram com base na razão: "alguns argumentam, de maneira convincente, que o antissemitismo nazista e stalinista, por mais mortal que fosse, em última análise, obedeceu a objetivos racionais" (p.45).

Em um relato inocente de Günter Grass, Steiner ainda afirma: "Há um vínculo secreto e eterno entre judeus e fascistas, uma identidade oculta ou atração mútua mais profunda do que manifestações ostensivas de desprezo ou violência. [...] É devido ao próprio judaísmo que o nazismo desenhou sua própria fé em uma raça "eleita", seu nacionalismo milenar e messiânico. [...] A comunidade judaica da Alemanha atraiu o furacão sobre sua própria cabeça, insidiosamente lisonjeando os desejos sutis da besta. 0 extermínio, também calculado e total, só pode implicar uma cumplicidade oculta entre a vítima e o executor". Alguns anos mais tarde, as teses de Steiner foram expostas de maneira mais grosseira, em um romance com uma tese, Le Transport de $A$. $H$, que retrata Hitler, encontrado vivo na Amazônia por um comando israelense que Steiner não poupa clichés de antissemitismo. Com disenteria, eles são "fedidos" enquanto Hitler, no papel do nobre velho, por sorte finalmente cresce. Jesus é um judeu que perseguiu a humanidade, muito mais do que Hitler: "O Nazareno, nesta terra, fundou uma Igreja de escravos. Eles são homens e mulheres, criaturas de carne, a quem ele abandonou a esta chantagem infernal da punição eterna. 0 que são os nossos campos de concentração em comparação com isso"? (p.244). Este Hitler ressuscitado retoma os temas do fanatismo antirreligioso de Nietzsche para justificar os acampamentos produzidos pelo bolchevismo judeu "Marx e seus seguidores eram judeus [...] toda turma do bolchevismo Trotsky, Rosa de Luxemburgo, Kamenev, toda a multidão fanática e assassina saiu de Israel" (p.245). Esta personificação de Hitler, em nossa opinião, torna-se particularmente grave porque dá voz não às vítimas, mas ao chefe assassino que os coloca, em acusação póstuma. 
Embora Steiner alegue ser um sobrevivente, sua escrita contraria o projeto de Levi, dando voz às vozes devoradoras. Aprendido de um rabino "oleoso" para quem Hitler pintava cartões postais durante sua juventude em Munique, o racismo nazista seria, portanto, uma imitação da doutrina judaica da eleição, o Reich um prenúncio de Israel "um único Israel, um único povo, um único líder" (p.240).

0 processo de judaizar Hitler e nazificar Israel é retirado da obra do neonazista Hennecke Kardel, autor de Adolf Hitler Begrunder Israels (1974), onde o ditador, tornado "meio-judeu", é retratado como o inspirador de Israel. Alvin Rosenberg enfatiza em seu livro Imagining Hitler (Bloomington, Indiana University Press, 1985), retomadas flagrantes que revelam este livro como uma fonte de Steiner.

Steiner consegue rever Mein Kampf, que não é inspirado por um rabino ou Herzl, mas pelos tribunos extremistas da época, Lüger e Ungerer. Para ser tão prejudicial, Hitler deveria ser judeu: "Somente um judeu poderia fazer de qualquer judeu um morto-vivo". [...] Hitler, o judeu ", diz seu personagem Elie Barach (p.140).

(II) Em seu tributo jubilar a Heidegger (1969) Arendt dá um exemplo de tal pensamento, ilustrando, pelo menos, com um fenômeno de influência. Em uma longa nota, não no texto, ela trata extensivamente da relação de Heidegger com o nazismo, reduzindo-o a uma "fuga" (p.318), como se poderia dizer de um fim de semana prolongado em paixão. Ela afirma calmamente: "0 importante é que Heidegger, como tantos outros intelectuais alemães, nazistas e antinazistas, de sua geração, nunca leu Mein Kampf", enquanto em 1932, ele recomendou, calorosamente, sua a leitura a seu irmão e que, em seus seminários, encontramse reescrituras essenciais desta obra.

Segundo a autora, Heidegger "teria assumido muito mais risco do que os então correntes na Universidade Alemã. Mas não se pode dizer o mesmo dos inumeráveis intelectuais que se diziam sábios, não somente na Alemanha, que preferem, mais e mais, em vez de falar de Hitler, Auschwitz, genocídio e da "eliminação" como uma política de despovoamento permanente, aderir, cada um com sua própria fantasia e gosto, a Platão, Lutero, Hegel, Nietzsche ou mesmo a Heidegger, Jünger ou Stefan George, para disfarçar, de certa maneira conforme as humanidades e a história das ideias, o fenômeno aterrorizante oriundo do esgoto". Antológica, esta acusação de intelectuais desafia as ciências humanas e a história das ideias a desculparem Heidegger. Isto não tem nenhuma relação com Hitler, apesar da edificante profissão de fé em favor de Adolf Hitler, que ele teve o cuidado de coletar no volume 16 de suas obras completas, mesmo quando Arendt invoca Platão, na página anterior, para traçar um paralelo entre Hitler e Denys de Siracusa. Além disso, que riscos Heidegger correria? Seria corajoso discriminar os estudantes judeus, por presidirem uma pira simbólica de livros?

A imagem do "campo" dispensará Arendt de toda análise aprofundada. Identificandose-com totalitarismo, ela isenta a Itália fascista que, segundo a autora, não teria sido totalitária, por falta de importantes campos. A iconização do campo permaneceu tão expressiva que, durante muito tempo, atrasou a historiografia do Holocausto por balas. Reduzir o extermínio à instituição dos campos certamente impressiona a imaginação, mas bloqueia a compreensão do nazismo: Arendt foi capaz de retomar, assim, a noção confusa de totalitarismo para aplicar ao Lager alemão, como ao Gulag stalinista, até mesmo às prisões macarthistas, a tudo enfim excetuando a Itália fascista.

Na única frase que proferiu no extermínio, Heidegger afirmou que o bloqueio de Berlim pelos russos o transformou em um campo de extermínio. Ele acrescenta nos Cahiers Noirs que a Alemanha desde a derrota se tornou um vasto campo.

O essencial é que as concepções de Heidegger e Arendt estejam inextricavelmente ligadas. Sobre tudo isso, o último livro de Emmanuel Faye forneceu um esclarecimento decisivo. 
Resta que, em 9 de setembro de 2017, no Memorial da Shoah, o historiador Johann Chapoutot, Professor na Universidade de Paris-Sorbonne, Paris IV, retomou, por sua conta, surpreendentemente, os estereótipos apologéticos sobre Heidegger e Arendt: "Aqui ele aprendeu que os judeus mataram Cristo em grosso, eles tem um nariz torto e [...] eles amam dinheiro [...] eles estão saqueando o povo alemão a granel. Mas isto não é ser um nazista; não faz dele um nazista. Mas porque um nazista que tem um caso de amor com um judeu não existe de fato. Ele não existe, hein? Não há nenhum, é isso. E o grande amor de sua vida é Hannah Arendt. Isso é [...] .E, aliás, Heidegger, que acredita poder fazer carreira com os nazistas, dissocia-se deles muito rapidamente. Na primavera de 1934, ele renunciou ao cargo de reitor. E entra em uma forma, se não de resistência pelo. menos de resmungos por dentro. Em cursos, no seminário, ele diz coisas muito difíceis sobre os nazistas, muito, muito duras. Seu trabalho é imenso. Como se salvo pelo "grande amor de sua vida", Heidegger não seria um verdadeiro nazista, mas um oportunista temporário, até mesmo um antinazista secreto. Esta versão flor azul amplamente atestada o teatro como cinema, tem sido, no entanto, prejudicada tanto por Emmanuel Faye como por Sidonie Kellerer (como foi evidenciado pela entrevista que ela, recentemente, lhe concedeu).

(III) Leo Strauss participou de alguns seminários de Heidegger em Marburg, mas ele não é um discípulo, contrariamente ao que propaga um insistente boato entre os heideggerianos. Ele apoiou em 1921 sua tese sobre Jacobi com Cassirer e reconheceu Lessing como sua principal inspiração para o método. Ele também criticou duramente Heidegger. É o caso de Heidegger, que se interessou pelo trabalho de Strauss sobre criptografia em filosofia ... com o sucesso que conhecemos. Strauss não tinha complacência com o nazismo, como evidenciado por suas palestras coletadas no Niilismo e política. Ele lutou com Carl Schmitt teoricamente, refutando notavelmente sua leitura de Hobbes. Enquanto conservador, foi erguido pelo grupo de Lyndon LaRouche à categoria de inspiração póstuma de alguns neoconservadores que aconselharam George Bush, mas esse boato é sem fundamento sério e relatos de algumas teorias da conspiração antissemita.

\section{A.G. - 0 senhor poderia explicar o que chama de "MacDonaldisação de Auschwitz" pela filosofia do pop?}

FR. - Na conferência "Heidegger e os judeus", realizada em Paris no início de 2015, em reação à publicação dos primeiros Cahiers Noirs, Babette Babich concluiu sua contribuição com um paralelo entre a exterminação e o consumo de carne: "Em poucas horas, teremos o almoço, um almoço onde os animais continuam a desempenhar para nós o papel dos judeus" (Regra do Jogo, 59/60, 2016, 445). A partir desse paralelo, que humaniza tanto os animais de açougue quanto animaliza os judeus, o extermínio é diluído em uma rotina diária. Reformulada por Babich, a metáfora heideggeriana que faz o paralelo entre extermínio e a indústria de alimentos, vê-se, ainda, atualizado por Steinbock quando ele comenta o texto heideggeriano, assimilando o extermínio e industrialização da agricultura: "A indústria de alimentos se transformou em fast food" (cit., 317), completando assim a macdonaldização de Auschwitz. A analogia é tanto mais repulsiva quanto relembra, obscuramente, os antigos holocaustos, coroados por banquetes de feras sacrificadas.

\section{A.G. - O pensador lacano-marxista Slavoj Žižek disse: "Os sionistas são os únicos e verdadeiros antissemitas". Jacques Lacan, próximo de Jean Beaufret, que defendeu Robert Faurisson até o fim, ele introduziu uma parte do negacionismo na psicanálise?}

FR. - Vou separar minhas respostas. Žižek acredita que Hitler não foi longe o suficiente. Este argumento volta, hoje, no discurso vermelho-marrom de alguma filosofia pop. 
Então, Em defesa de causas perdidas, Žižek afirma, claramente, que Heidegger não é grande apesar de seu envolvimento nazista, mas, precisamente, graças a ele, e até mesmo critica Hitler por não ter sido "suficientemente violento". Ele também estava convencido do plágio de um artigo de Stanley Hornbeck, intitulado "Procure o judeu", publicado em uma revista de supremacia branca, American Renaissance (10, 3, março de 1999), que deve tê-lo reconhecido, mas foi liberado sobre um assistente. Isso não o impediu de codirigir, com Badiou, várias obras dedicadas à condenação da democracia e ao elogio de certo "comunismo".

Em sua juventude, Lacan pediu sem sucesso a Maurras que esse se tornasse seu "diretor de consciência". Ele foi o primeiro na França a receber Heidegger, quando este veio ao colóquio de Cerisy que, por iniciativa de Beaufret, permitiria encobrir Heidegger e fazer da França a base da reconquista da opinião internacional. Não vou me encarregar de medir a extensão do compromisso de Lacan com o heideggerismo. Vejo, com interesse, que Yann Diener tomou a iniciativa de um seminário "Lacan sem Heidegger", realizado em Paris como parte do ELP, a Escola Lacaniana de Psicanálise.

\section{A.G. - 0 senhor diz que a maioria dos debates filosóficos na web tratam de Martin Heidegger. Como o senhor explica isso?}

FR. - Eu estava me referindo à "filosofia da web" tal como ela aparece nos congressos internacionais da WWW de que participei por motivos profissionais. Trabalhei por muito tempo em inteligência artificial e ainda estou associado a um laboratório que lida com corpora numéricos multilíngues. Os círculos de computação estão, naturalmente, interessados na questão da tecnologia, mas falta ensino epistemológico nos cursos, bem como referências. 0 livro de Hubert Dreyfus, $O$ que os computadores não podem fazer? Os limites da Inteligência Artificial, publicado em 1972, tornou-se um clássico. Ele criticou, do ponto de vista de uma fenomenologia de inspiração heideggeriana, a tese cognitivista (e maximalista) de que esse pensamento é uma manipulação de símbolos que poderiam ser imitados por cálculos. Para ele, seria o oposto de um Ser-no-mundo, dependendo de forças instintivas amplamente inconscientes.

Já nos anos 50, Heidegger condenou a cibernética sem apelar. Em alguns círculos intelectuais, Heidegger passa por ter "pensado" a técnica por suas condenações do mundo moderno. Mas em 1939 ele proclamou que a "motorização da Wehrmacht" era "metafisicamente necessária". Após a derrota hitlerista, ela é condenada sem apelo e convenientemente responsabilizada pelo extermínio, colocada no mesmo nível da industrialização da agricultura.

Nos Cahiers Noirs, aparece claramente que a condenação da técnica, principalmente da cibernética, é baseada em uma teoria da Machenschaft, a maquinação judaica: o estereótipo do usurário judeu é suficiente para condenar qualquer cálculo, tanto os matemáticos quanto à informática.

Lembre-se de que não há em toda a obra de Heidegger nenhuma análise de qualquer dispositivo técnico. Ela está limitada a dois ou três exemplos, como as setas de direção dos carros daquela época.

A.G. - 0 senhor pode comentar essas palavras de Jean-Luc Nancy?: "Pois o que (Heidegger) acreditava, realmente, pertencer a um "arqui-fascismo" (a palavra é de Lacoue-Labarthe) também pode ser descrito como arquimessianismo desse «outro começo» que ele continua a invocar (e é por isso que ele queria a publicação póstuma destes textos, imaginando que mais tarde seriam melhor compreendidos ...) « . (Libertação )

FR. - Heidegger detestava o fascismo, que ele considerava não-germânico, por isso é muito mais de arqui-nazismo que se deveria falar. Ele multiplicou iscas messiânicas, com o 
efeito, se não o propósito, de reunir os discípulos judeus, porque ele pretendia também destruir o judaísmo a partir do seu interior.

Nos Cahiers noirs, ele se permite fazer profecias: anuncia seriamente o fim do "americanismo" para o ano da graça de 2327, exatamente quatro séculos depois de Sein und Zeit. Você compreende, portanto, que o próprio trabalho dele tem uma dimensão messiânica e opera a irrupção dos últimos tempos, os Ereignis. Eu desenvolvi essas questões em um livro que se encontra no prelo: Heidegger, o Messias antissemita. $O$ que revelam os Cahiers noirs, a ser publicado em setembro 2018.

Jean-Luc Nancy publicou um posfácio para um artigo de Robert Antelme, uma importante testemunha dos campos, intitulado Vingança? (Paris, Hermann, 2010, pp. 39-46) Ele conclui: "Devemos ser capazes de discernir os efeitos sorrateiros da vitória sobre o fascismo" (p.45); "Conhecemos, desde 1945, muitas outras figuras fingidas do Mal [que a Alemanha], vimos um espírito de cruzada reviver onde o desejo de vingança se lisonjeia em agir em nome dos valores da democracia, do direito e do humanismo "(p.44). "Assim, a data de 1945 não é a de uma libertação, mas sim de uma catástrofe desenfreada que deslegitima Nuremberg, a justiça internacional, a restauração da democracia e dos direitos humanos, todos "efeitos furtivos" da vitória sobre o fascismo".

Quatro dias após o ataque de 14 de julho de 2016 em Nice, Nancy publicou no Libération um breve artigo intitulado "Um caminhão lançado ...", que passou quase despercebido, mas não perdeu nada de seu interesse. Aqui está o começo: "Um caminhão lançado para esmagar crianças — entre outros — dá uma imagem insuportável de niilismo". 0 próprio niilismo nomeia um cume: o da nossa história e da nossa civilização. (...) Temos que nos assumir, que empreender nosso negócio universal de poder nunca satisfeito. Temos que embarcar e desmontar os caminhões malucos do nosso suposto progresso, nossas fantasias de dominação e nossa obesidade de mercado". O leitor não saberá quem dirigia o caminhão (Mohamed Lahouaiej Bouhlel, um francês-tunisiano de trinta e um anos): "jogado" como se o motorista tivesse tirado de marcha na estrada, torna-se um "caminhão maluco" que escapa ao controle. 0 autor não diz quem reivindicou o ataque (Daesh); nem que o ataque tenha deixado oitenta e seis mortos e quatrocentos e cinquenta feridos. As vítimas não são detalhadas: não se faz, entretanto, diferença que trinta e sete sejam estrangeiros pertencentes a dezenove nacionalidades. 0 próprio fato do crime não é qualificado (a palavra atentado está ausente do artigo), seu agente permanece apagado, como a organização que reivindica este crime em massa, cuja própria gama de vítimas evoca um crime contra a humanidade. 0 simbolismo, embora cuidadosamente escolhido, escapa: em 14 de julho, era obviamente uma questão de alcançar a democracia, tão desanimada por Daesh quanto ridicularizada por Jean-Luc Nancy. (ver, por exemplo, na companhia de Giorgio Agamben, Alain Badiou, Democracia, em que estado?; e Verdade da Democracia, 2008).

Essa curta retratação assemelha-se a uma forma discreta de negacionismo e permite uma inversão de responsabilidades: "É necessário cuidar de nós mesmos". Para que isto fique mais claro, procuremos, portanto, quem é esse "nós" na "nossa história", "civilização", "nossa empresa universal de poder", "nosso suposto progresso", "nossas fantasias de dominação", "nossa obesidade de mercado". Neste último ventre, teremos reconhecido o Ocidente plutocrático e pós-colonial. Heidegger considerava o niilismo como o destino da história ocidental e pretendia, como vimos, que os judeus se tivessem exterminado entre si. Aqui o niilismo implica a destruição do Ocidente para Nancy, ele próprio se esvaziou e só ele é responsável, sem que seja necessário evocar a ajuda entusiástica e altruísta jihadistas.

Como os leitores críticos seriam incapazes de ler Heidegger e muito menos de traduzilo, suas objeções são imediatamente descartadas por serem irrisórias. Como médica séria, 
Nancy (.......) diagnostica, repetidamente, a "dislexia" de Sabine Prokhoris, Sidonie Kellerer, Emmanuel Faye sem esquecer a minha. Para atender a esses "ministradores de aula" boa aula de leitura impõem-se: "a ele como outros ministradores que peço gentilmente que reflitam sobre duas citações nem mal recortadas ou adulteradas, mas escolhidas por serem breves entre centenas de outras possibilidades". Eis a segunda: "Como o socialismo nacional, o judaísmo é a tentativa vã de fazer com que a" maquinação "sirva a seus próprios fins. "Maquinação" continua sendo o verdadeiro poder (GA 95, 450)". Ora, Sidonie Kellerer sublinhou essa frase que une, providencialmente, o judaísmo e o nazismo em uma maquinação (Machenschaft) comparável, não apenas a um Heidegger que se tornou crítico do nazismo, mas a Peter Trawny, no posfácio daquele volume. Como o duque de Guermantes que confundiu Balzac e Celeste de Chabrillan porque ele os uniu na mesma tonalidade, Nancy, levado pelo impulso de sua lição, a concluiu assim, sem estar ciente de qualquer coisa: "Que queiramos ler, é tudo que eu peço [...] volto às minhas leituras". Nós podemos apenas encorajá-lo.

Além de Heidegger, é preciso lembrar o sucesso internacional de seus amigos e colegas, como Schmitt, participante como ele da Comissão para a filosofia do direito que tem contribuído para a elaboração das Leis antissemitas de Nuremberg, e reuniram como ele sua limpeza. Eles estão agora no campo editorial das coleções francesas de maior prestígio, com Drieu La Rochelle, Rebatet, Céline e Maurras.

$\mathrm{Na}$ véspera de sua morte, Cassirer formulou um projeto que ultrapassa o próprio nazismo para abranger todas as teologias políticas: aquela de começar a "estudar cuidadosamente a origem, estrutura e técnica dos mitos políticos", o que nos permitirá "olhar a face do adversário para saber como combatê-lo".

Mesmo supondo que os filósofos franceses tivessem necessitado de um alemão para pensar, ou só pudessem pensar em alemão, como disse o Mestre, é surpreendente que, malgrado sua pretensão cartesianista "genética", eles tenham escolhido Heidegger em vez de Cassirer. Chegou a hora de transformar esta página questionável.

0 pensamento de Cassirer, por outro lado, não se reduz a uma reminiscência do racionalismo clássico, porque considera o conceito de razão inadequado para descrever as formas de cultura em sua diversidade (ver Ensaio sobre o homem). Ele traça o programa de uma filosofia das culturas que o heideggerismo, tenso por uma obsessão identitária disfarçada em ontologia, só fez atrasar.

A propósito das ciências, Heidegger quis aniquilar seu projeto de conhecimento, sua metodologia, suas ligações recíprocas, levando o irracionalismo ao auge. Por que estudar, como fez Cassirer, o programa de Erlangen, as geometrias não-euclidianas, a física quântica, a linguística histórica e comparada, a mitografia, a antropologia? Desenvolvidas a partir de Humboldt, e ilustradas por autores como Cassirer, Boas, Saussure, Panofsky, Jakobson, LéviStrauss, Hocart, Benveniste, Simondon, Leroi-Gourhan e muitos outros, as ciências culturais têm desenvolvido uma compreensão do mundo humano em suas diferentes formas simbólicas. Mas por que levar em conta as revoluções científicas quando o Pensamento é suficiente para reivindicar uma ignorância deliberada, sedutora porque, fácil de entender, ela convence pela retórica identitária dos tiranos, como os demagogos, e se reveste, por outro lado, com os atavios de uma superioridade?

\section{FONTE:}

http://frblogs.timesofisrael.com/dialogue-avec-francois-rastier/ 